\title{
Identification of LMO2 as a new marker for acinic cell carcinoma of salivary gland
}

Dong Sheng ${ }^{1,2+}$, Yan Zhang ${ }^{1,2+}$, Tian Xue ${ }^{1,2}$, Xiao-Yan Zhou ${ }^{1,2}$ and Xiao-Qiu Li $i^{1,2^{*}}$

\begin{abstract}
Background: The distinction between acinic cell carcinoma (ACC) and secretory carcinoma (SC) of the salivary gland is hampered by the lack of specific diagnostic markers. It is known the cytoplasm of glandular cells in the salivary gland immunohistochemically expresses LIM Domain Only 2 (LMO2). Herein, we aim to evaluate the expression status of $\mathrm{LMO} 2$ in a large cohort of tumors of the salivary gland, with an emphasis on its significance in the distinction of ACC and SC.
\end{abstract}

Methods: Immunohistochemical stains were performed to evaluate the expression of LMO2 in normal tissues and tumors of salivary gland.

Results: LMO2 was expressed in normal serous acinar cells of the salivary gland. We also found the cytoplasmic immunostaining of $\mathrm{LMO} 2$ was specific and sensitive for the recognition of ACCs including those with morphological overlaps with SCs, whereas the cytoplasmic expression of LMO2 was not detected in SCs.

Conclusions: LMO2 is useful for the recognition of ACC and is of potential value in distinguishing ACC from SC.

Keywords: Acinic cell carcinoma, Secretory carcinoma, Salivary gland, LMO2

\section{Introcuction}

Acinic cell carcinoma (ACC) of the salivary gland is generally considered a low-grade tumor with high recurrence rates [1]. While conventional ACCs feature serous acinar cell differentiation and rich cytoplasmic zymogen granules, the proportion of the neoplastic serous acinar cells varies considerably from case by case, and some cases may comprise additional neoplastic intercalated duct-resembled cells, vacuolated cells or clear cells. In addition, the morphologic diagnosis of high-grade transformed ACCs that lack pathognomonic serous acinar cells or zymogen granules-poor ACCs (prominent intercalated duct-like pattern) can be difficult $[2,3]$. Therefore, the distinction between ACCs and other tumors of

\footnotetext{
* Correspondence: leexiaoqiu@hotmail.com

${ }^{\dagger}$ Dong Sheng and Yan Zhang contributed equally to this work.

'Department of Pathology, Fudan University Shanghai Cancer Center, 270

Dong-An Road, Shanghai 200032, China

2Department of Oncology, Shanghai Medical College, Fudan University,

Shanghai, China
}

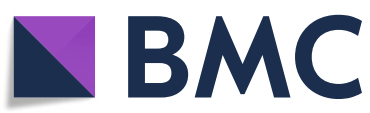

the salivary gland, especially secretory carcinomas (SC), may pose a significant challenge due to their histomorphologic similarities. It has been characterized that SC possesses the ETS variant 6 (ETV6) gene rearrangement, which can be demonstrated by a fluorescence in-situ hybridization (FISH) [4], whereas specific diagnostic markers for ACCs and immunohistochemical markers for distinguishing these two types of salivary gland tumors need to be further explored.

LIM Domain Only 2 (LMO2) is an evolutionarily conserved protein involved in family of the transcription factor necessary for hematopoiesis and angiogenesis [5]. High level of LMO2 has been detected in various organs or tissues including normal glandular cells of the salivary gland according to the publicly available data set of the Human Protein Atlas (http://www.proteinatlas.org). Moreover, LMO2 has been reported including normal glandular hematolymphoid tumours includinga subset of germinal-center-derived B-cell lymphomas and the $\mathrm{T}$ lymphoblastic leukemia/lymphoma [6, 7].

(c) The Author(s). 2022 Open Access This article is licensed under a Creative Commons Attribution 4.0 International License, which permits use, sharing, adaptation, distribution and reproduction in any medium or format, as long as you give appropriate credit to the original author(s) and the source, provide a link to the Creative Commons licence, and indicate if changes were made. The images or other third party material in this article are included in the article's Creative Commons licence, unless indicated otherwise in a credit line to the material. If material is not included in the article's Creative Commons licence and your intended use is not permitted by statutory regulation or exceeds the permitted use, you will need to obtain permission directly from the copyright holder. To view a copy of this licence, visit http://creativecommons.org/licenses/by/4.0/ The Creative Commons Public Domain Dedication waiver (http://creativecommons.org/publicdomain/zero/1.0/) applies to the data made available in this article, unless otherwise stated in a credit line to the data. 
Nevertheless, the applicability of LMO2 in the diagnosis of tumors of the salivary gland, has never been assessed.

In the current study, we validate the diagnostic usefulness of LMO2 by assessing the expression status of LMO2 in the normal tissues and tumors of the salivary gland, including ACCs and SCs.

\section{Methods}

\section{Patient selection}

A total of 176 eligible cases, including ACC $(n=30)$, SC $(n=11)$, mucoepidermoid carcinoma $(n=22)$, adenoid cystic carcinoma $(n=26)$, polymorphous adenocarcinoma $(n=13)$, salivary duct carcinoma $(n=15)$, basal cell adenocarcinoma $(n=1)$, myoepithelial carcinoma $(n=2)$, epithelial-myoepithelial carcinoma $(n=2)$, pleomorphic adenoma $(n=15)$, basal cell adenoma $(n=15)$, myoepithelioma $(n=1)$, warthin tumor $(n=15)$ and oncocytoma $(n=8)$, were retrospectively reviewed and studied. All tumors were excised specimens and were diagnosed between 2008 to 2018. Diagnostic confirmation was obtained through a review by three independent pathologists (D.S., Y.Z., and X.-Q.L.) according to the criteria of the 2017 revised World Health Organization classification. In addition, ACCs were classified as conventional low-grade ones or high-grade transformed tumors in line with observed pleomorphism, necrosis or mitotic counts $[2,8]$. ACCs with paucity of zymogen granules (prominent intercalated duct-like variant) were identified as tumors with a low proportion of serous acinar cells but a high proportion of intercalated duct-like cells, and without an ETV6 gene rearrangement [9].

\section{Fluorescence in situ hybridization}

In the current study, FISH was carried out on the formalin-fixed and paraffin-embedded (FFPE) specimens of ACCs and SCs. Detection of ETV6 gene rearrangement was performed with a Vysis LSI ETV6 Dual Color Break Apart Rearrangement Probe (Abbott Molecular, Des Plains, IL) according to the protocols specified by the manufacturer. A total of 50 interphase nuclei were counted for each hybridization test. The presence of ETV6 gene breaks was defined as follows: the presence of $>20 \%$ split signals observed in the tumor cells.

\section{Immunohistochemistry}

Antibodies including LMO2 (1A9-1, Roche/Ventana, Tucson, AZ, USA), DOG1 (SP31, Maxim, Fuzhou, China), and S-100 (Dako, Santa Clara, CA, USA) were applied according to the manufacturer's instructions [4, 10-12]. FFPE specimens of all the tumors as well as normal salivary gland tissues were immunostained.
According to the prior studies, a percentage of $>30 \%$ of tumor cells with cytoplasmic staining of LMO2 was considered to be positive expression [7]. Whereas nuclear or membranous staining was regarded as nonspecific. The immunostaining of DOG1 and S-100 was evaluated as previously described [12]. All the IHC results were confirmed by three independent pathologists (D.S., Y.Z., and X.-Q.L.).

\section{Statistical analysis}

Fisher's exact test was used with GraphPad Prism 9 and results were considered to be statistically significant at a $P$-value $<0.05$.

\section{Results}

\section{The clinicopathologic features of patient cohort}

The clinicopathologic characteristics of the 30 cases with ACC of salivary gland were summarized in Table 1. A considerable number of cases were classic lowgrade ones, whereas high-grade transformation was only observed in one case. And 4 cases with zymogenpoor tumors were identified. The clinicopathologic details of the $11 \mathrm{SC}$ cases were shown in Table 2. The immunostaining of the ACC marker DOG1 showed positive results in $24 \mathrm{ACCs}$, and was weakly positive in 5 additional ACCs and focally positive in $3 \mathrm{SCs}$, and the SC marker S-100 was expressed in 10 SCs and weakly positive in 4 ACCs, possibly suggesting that both antibodies are not very specific for the diagnosis. ETV6 gene rearrangement was detected in all SC cases but none of ACC cases.

\section{The expression of LMO2 in normal salivary gland tissues}

To assess whether LMO2 was expressed in normal salivary gland, IHC detect on using in FFPE samples of 10 normal salivary glands was performed. All the specimens showed consistent and intensive cytoplasmic staining of LMO2 in serous acinar cells (Fig. 1), whereas other cell types showed negative or sometimes weak positive results (Fig. 1).

\section{The expression of LMO2 protein in tumors of the salivary gland}

IHC detection showed that all the classic ACCs displayed a remarkable strong and diffuse cytoplasmic expression of LMO2 (Fig. 2, Table 1). Moreover, the cases with high-grade transformation or poor zymogen granules also showed strong cytoplasmic LMO2 staining (Fig. 3, 4, Table 1). The nuclear expression of LMO2 in germinal center $\mathrm{B}$ cells with the lesion could be used as a good internal positive control (Fig. 4B, red arrow), while the other types of lymphocytes without LMO2 expression served as negative controls (Fig. 4B, blue arrow). In contrast, the SC cases showed no cytoplasmic 
Table 1 Clinical and pathological features of ACCs of salivary gland

\begin{tabular}{|c|c|c|c|c|c|c|c|c|c|}
\hline Case ID & Sex & Age (yr) & Localization & Size $(\mathrm{cm})$ & Subtype & LMO2 & DOG1 & S-100 & ETV6 rearrangement \\
\hline 1 & $\mathrm{~F}$ & 34 & parotid gland & 0.8 & Classic &,$+ C$ & + & - & - \\
\hline 2 & $\mathrm{~F}$ & 58 & parotid gland & 2.2 & Classic &,$+ C$ &,$+ W$ & - & - \\
\hline 3 & $\mathrm{~F}$ & 42 & parotid gland & 1.5 & Classic &,$+ C$ &,$+ W$ & - & - \\
\hline 4 & $\mathrm{~F}$ & 51 & parotid gland & 0.9 & Classic &,$+ C$ &,$+ W$ & - & - \\
\hline 5 & $\mathrm{~F}$ & 19 & parotid gland & 2.6 & Classic &,$+ \mathrm{C}$ & + & - & - \\
\hline 6 & $\mathrm{~F}$ & 24 & parotid gland & 1.5 & Classic &,$+ C$ & + & - & - \\
\hline 7 & M & 58 & parotid gland & 2 & Classic &,$+ C$ & + & - & NA \\
\hline 8 & $\mathrm{~F}$ & 58 & parotid gland & 1.7 & Classic &,$+ C$ &,$+ W$ & - & - \\
\hline 9 & $\mathrm{~F}$ & 68 & parotid gland & 3.5 & Classic &,$+ \mathrm{C}$ &,$+ W$ & - & - \\
\hline 10 & $\mathrm{~F}$ & 65 & parotid gland & 2.5 & Poor zymogen granules &,$+ \mathrm{C}$ & + &,$+ W$ & - \\
\hline 11 & $\mathrm{~F}$ & 61 & parotid gland & 3 & Poor zymogen granules &,$+ C$ & + &,$+ W$ & - \\
\hline 12 & M & 55 & parotid gland & 1.6 & Classic &,$+ C$ & + &,$+ W$ & - \\
\hline 13 & $\mathrm{~F}$ & 54 & parotid gland & 2.8 & Classic &,$+ \mathrm{C}$ & + & - & NA \\
\hline 14 & M & 67 & parotid gland & 1.7 & Classic &,$+ C$ & - & - & - \\
\hline 15 & M & 65 & parotid gland & 4 & High-grade transformation &,$+ C$ & + & - & - \\
\hline 16 & M & 50 & parotid gland & 2.5 & Classic &,$+ C$ & + & - & - \\
\hline 17 & $\mathrm{~F}$ & 46 & parotid gland & 3.2 & Classic &,$+ C$ & + & - & - \\
\hline 18 & $\mathrm{~F}$ & 57 & parotid gland & 5 & Classic &,$+ C$ & + & - & - \\
\hline 19 & $\mathrm{~F}$ & 23 & parotid gland & 3 & Classic &,$+ \mathrm{C}$ & + & - & - \\
\hline 20 & $\mathrm{~F}$ & 31 & parotid gland & 2.5 & Classic &,$+ C$ & + & - & - \\
\hline 21 & M & 73 & parotid gland & 4.5 & Poor zymogen granules &,$+ C$ & + & - & - \\
\hline 22 & $\mathrm{~F}$ & 44 & parotid gland & 2.5 & Classic &,$+ \mathrm{C}$ & + & - & - \\
\hline 23 & M & 67 & parotid gland & 3.5 & Classic &,$+ C$ & + & - & - \\
\hline 24 & $\mathrm{~F}$ & 64 & parotid gland & 4 & Classic &,$+ \mathrm{C}$ & + & - & - \\
\hline 25 & $\mathrm{~F}$ & 79 & parotid gland & 3 & Poor zymogen granules &,$+ \mathrm{C}$ & + &,$+ W$ & - \\
\hline 26 & $\mathrm{~F}$ & 60 & parotid gland & 1.2 & Classic &,$+ C$ & + & - & - \\
\hline 27 & $\mathrm{~F}$ & 51 & parotid gland & 1.5 & Classic &,$+ \mathrm{C}$ & + & - & - \\
\hline 28 & $\mathrm{~F}$ & 28 & parotid gland & 2.4 & Classic &,$+ \mathrm{C}$ & + & - & - \\
\hline 29 & $\mathrm{~F}$ & 29 & parotid gland & 1.5 & Classic &,$+ \mathrm{C}$ & + & - & - \\
\hline 30 & M & 15 & submandibular gland & 2.5 & Classic &,$+ C$ & + & - & - \\
\hline
\end{tabular}

$M$ male, $F$ female, $C$ cytoplasmic, $W$ weak, $N A$ not available

Table 2 Clinical and pathological features of SCs of salivary gland

\begin{tabular}{lllllllll}
\hline Case ID & Sex & Age $(\mathbf{y r})$ & Localization & Size $(\mathbf{c m})$ & LMO2 & DOG1 & S-100 & ETV6 rearrangement \\
\hline 1 & $\mathrm{~F}$ & 62 & submandibular gland & 3 &,$+ \mathrm{N}$ & - & + & + \\
2 & $\mathrm{M}$ & 27 & parotid gland & 2 &,$+ \mathrm{N}$ &,$+ \mathrm{F}$ & + & + \\
3 & $\mathrm{~F}$ & 34 & parotid gland & 2.2 &,$+ \mathrm{N}$ & - & + & + \\
4 & $\mathrm{M}$ & 17 & parotid gland & 1.5 & - &,$+ \mathrm{F}$ & + & + \\
5 & $\mathrm{M}$ & 40 & parotid gland & 1.5 & - & - & + & + \\
6 & $\mathrm{M}$ & 61 & parotid gland & 3 &,$+ \mathrm{N}$ & - & + & + \\
7 & $\mathrm{M}$ & 42 & parotid gland & 3 &,$+ \mathrm{N}$ & - & + & + \\
8 & $\mathrm{M}$ & 40 & parotid gland & 1.8 & - & - & + & + \\
9 & $\mathrm{M}$ & 24 & submandibular gland & 1.5 & - & - & + & + \\
10 & $\mathrm{M}$ & 27 & submandibular gland & 2 & - &,$+ \mathrm{F}$ & + & + \\
11 & $\mathrm{M}$ & 57 & parotid gland & 2 & - & - & - & + \\
\hline
\end{tabular}



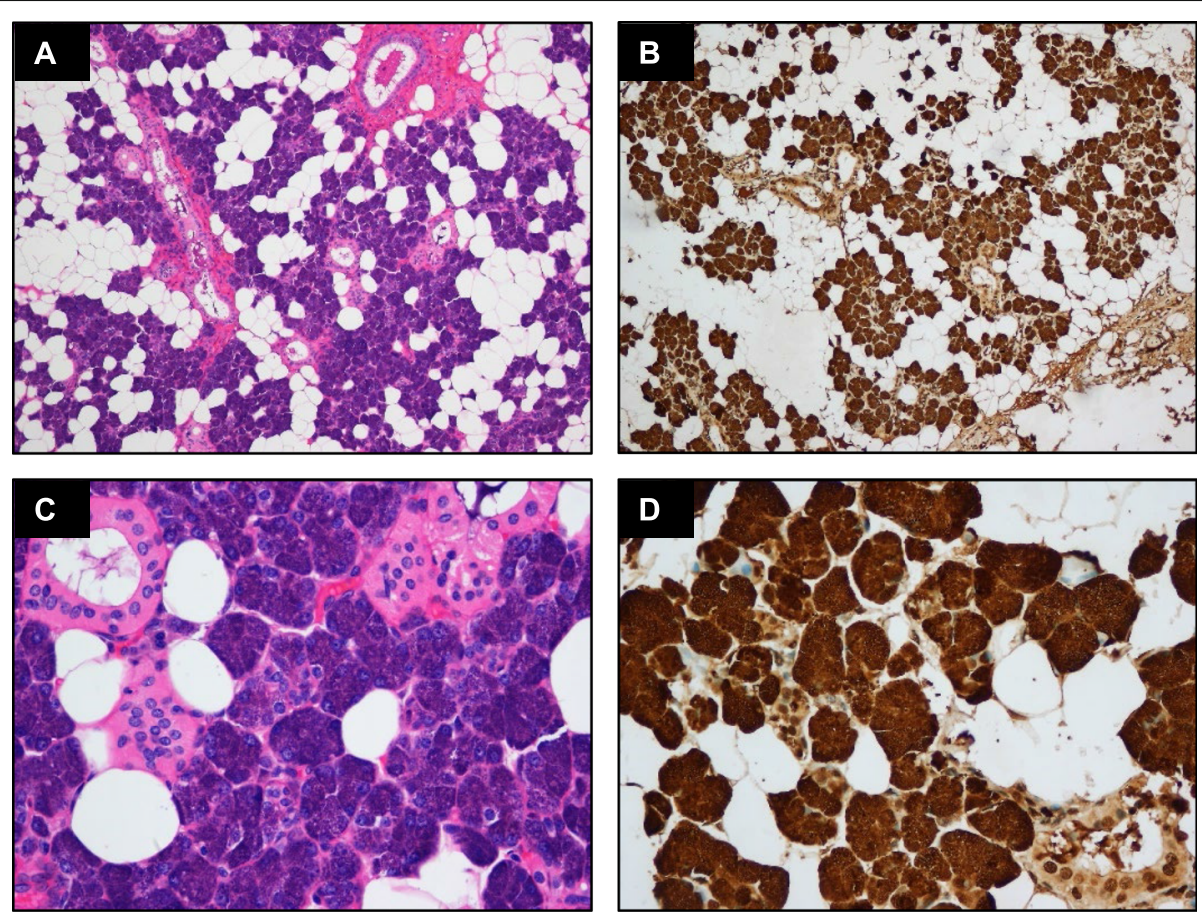

Fig. 1 (A) Histology of normal salivary gland tissue. (B) The normal serous acinar cells of the salivary gland shows strong and diffuse cytoplasmic staining of LMO2. (C-D) Higher power view
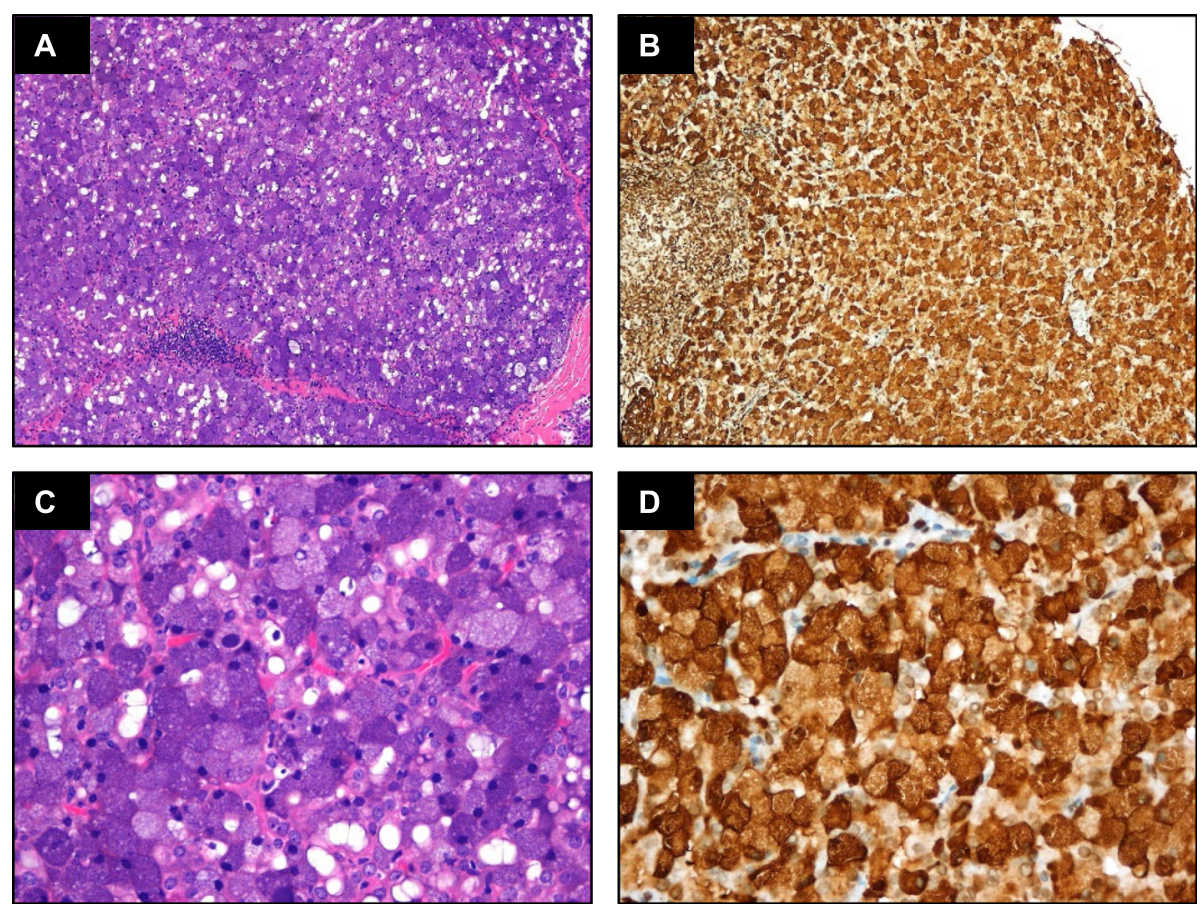

Fig. 2 (A) Histomorphology of a classic ACC. (B) The neoplastic cells express LMO2 in high levels. (C-D) Higher power view 

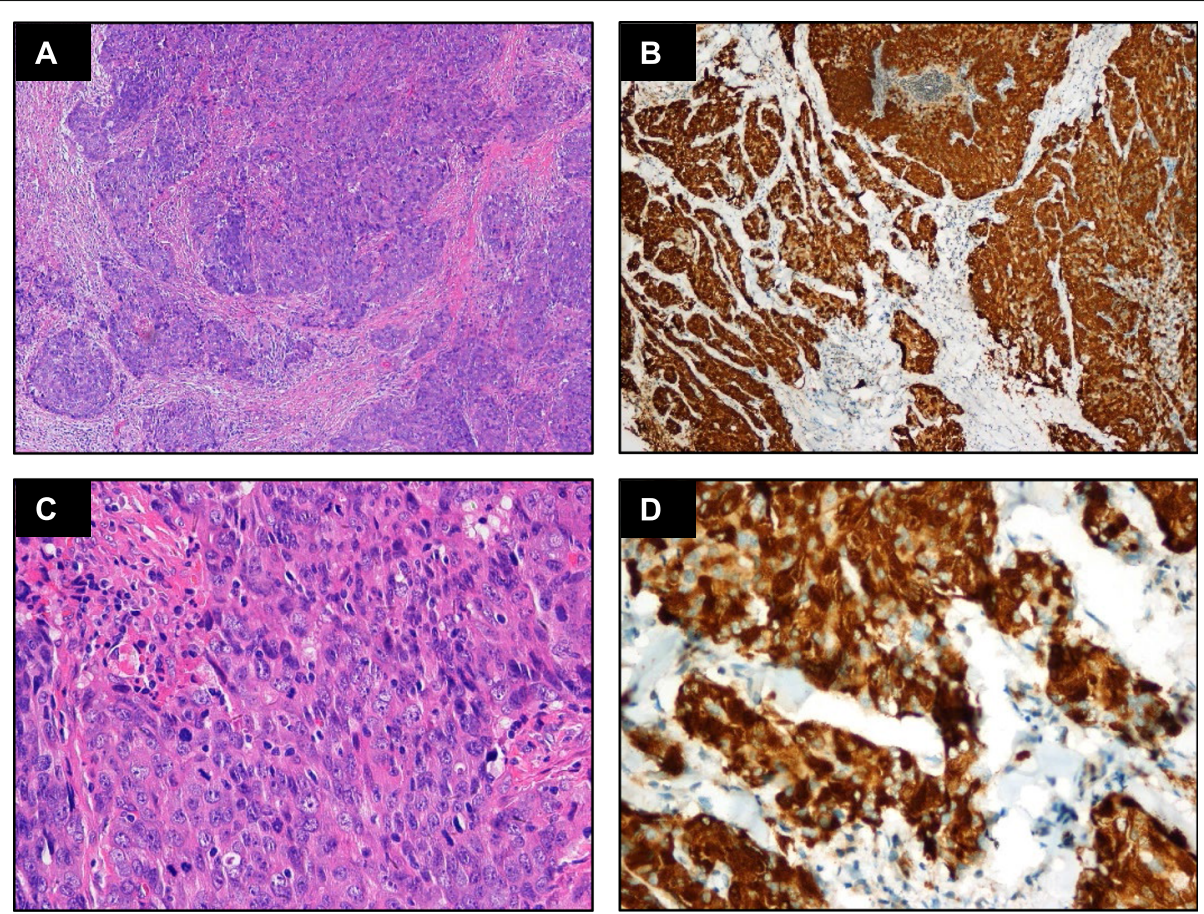

Fig. 3 (A) Histomorphology of a high-grade transformed ACC. (B) Intensive cytoplasmic LMO2 staining is seen in neoplastic cells. (C-D) Higher power view
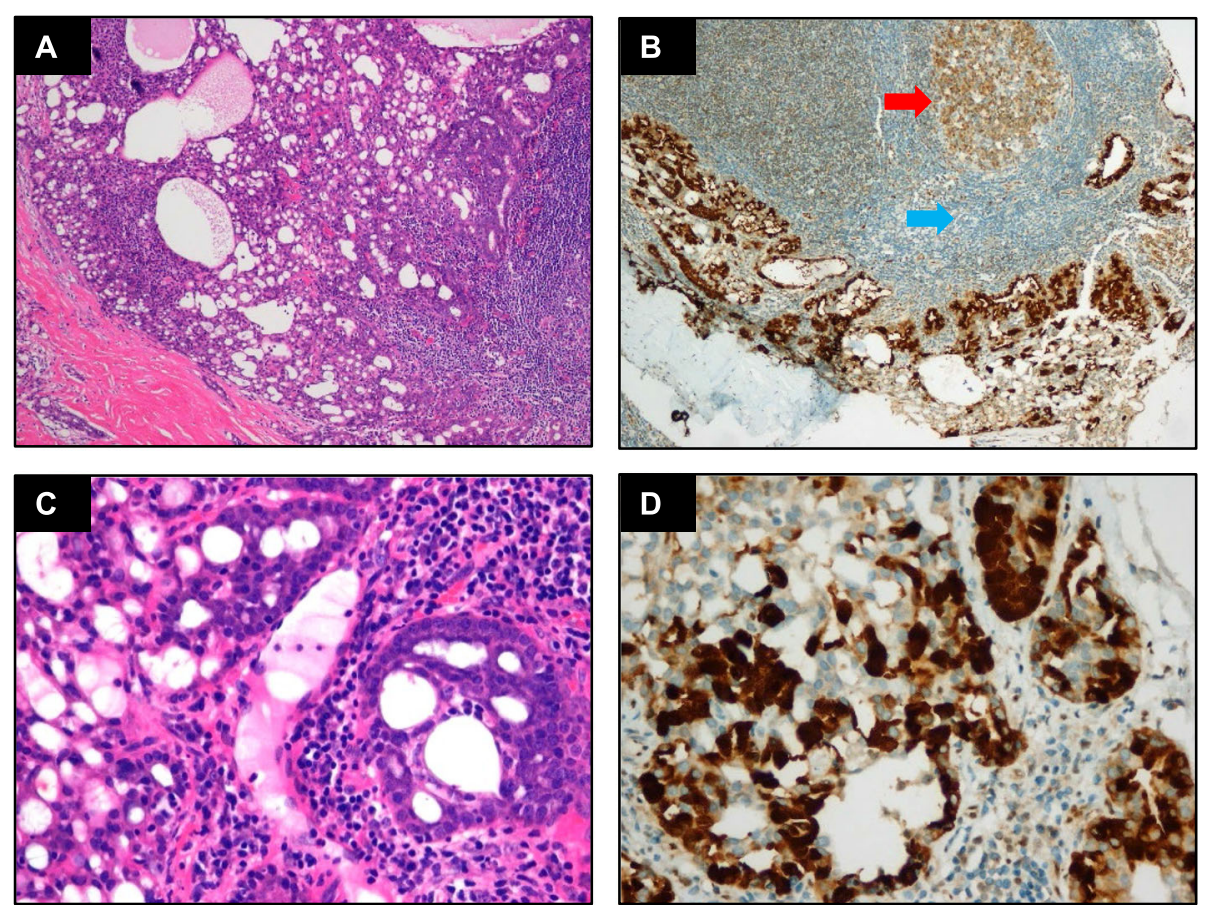

Fig. 4 (A) Histomorphology of a ACC with paucity of zymogen granules. (B) Strong cytoplasmic LMO2 staining is seen in the neoplastic cells. The nuclear expression of $\mathrm{LMO} 2$ in the germinal center B cells may serve as internal positive controls (arrow). (C-D) Higher power view 
expression pattern or just faint nuclear immunostaining of LMO2 (Fig. 5, Table 2). None of other salivary gland tumors expressed cytoplasmic LMO2 (Table S1). The statistical analysis of the cytoplasmic LMO2 expression showed significant differences between ACCs and other tumors of the salivary gland (Table S2).

\section{Discussion}

The classic form of ACC of the salivary gland usually features a serous acinar cell differentiation that morphologically shows a basophilic appearance with numerous cytoplasmic zymogen granules. However, some tumors are composed of a mixture of different neoplastic cells including serous acinar cells, intercalated duct-resembled cells, vacuolated cells and clear cells. The proportion of serous acinar cells is variable, and ACCs comprising predominantly of intercalated duct-resembled cells or vacuolated cells may show microcystic, cystic or follicular patterns. Sometimes the tumor cells of ACC may even display relatively an eosinophilic color mimicking SCs, which may cause challenges in the differential diagnosis $[9,13-$ 16]. ACC and SC are both low-grade salivary gland cancers and possibly differentiate from secretory cells of the salivary gland through different tumorigenic pathways. Currently, detection of the ETV6 gene rearrangement is identified as a gold standard for the recognition of SC, and aberrant gene changes like NR4A3 or MSANTD3 gene rearrangement have been reported to be related with some ACC cases [17-19]. S-100, mammaglobin, lysozyme and
pan-TRK are all valuable IHC markers for the diagnosis of SC, but these antibodies seem not so specific since which can be expressed in some other tumors of salivary gland [11, 20, 21]. IHC markers for ACC are even fewer, among which DOG1 may be the most useful one. However, it is not specific as well owing to its expression in other salivary gland tumors including adenoid cystic carcinoma, epithelial-myoepithelial carcinoma, salivary duct carcinoma, mucoepidermoid carcinoma, and even some SCs $[10,12]$. Periodic acid-Schiff (PAS) staining is frequently applied for highlighting the cytoplasmic zymogen granules, but such a method may sometimes be less sensitive in case of zymogen-poor ACCs [22]. In addition, The nuclear NR4A3 immunostaining introduced more lately by Haller et al. has been recently accepted as a novel diagnostic marker for ACCs [18], however, when we conducted the current study, such an antibody was not commercially available yet. In this study, we discovered cytoplasmic LMO2 staining was intensively positive in ACC cases. Compared with NR4A3, the advantages of LMO2 lie that it has been widely used, especially for the diagnosis of B-cell lymphomas and may be more easily commercially available [7]. In addition, normal expression of this marker in adjacent reactive tissues including serous acinar cells or follicular germinal center-derived B cells may serve as excellent internal positive controls.

LMO2 has been found to be expressed in many normal human tissues and various tumors, and currently, it seems to be a promising marker for identifying germinal center
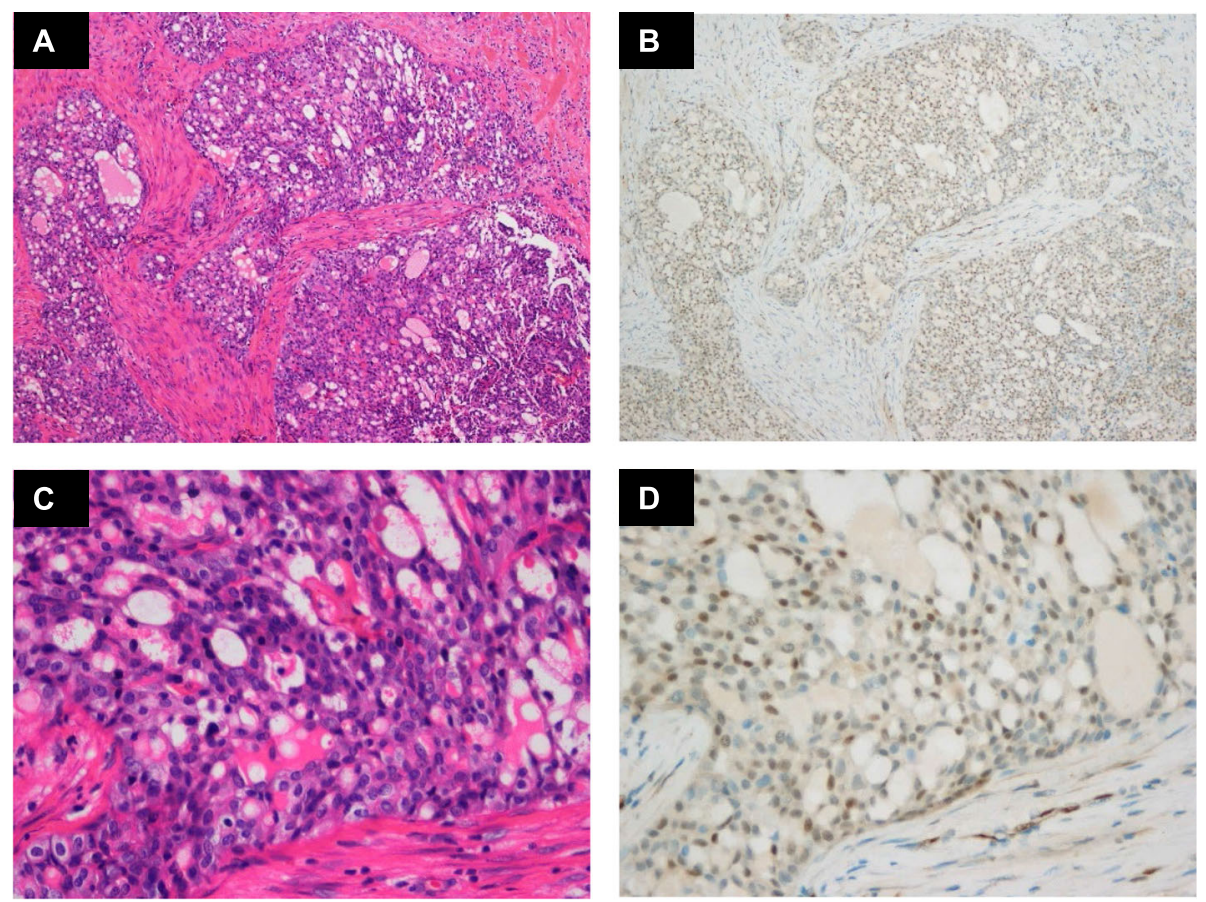

Fig. 5 (A) Histomorphology of a SC. (B) The neoplastic cells are weakly positive for LMO2 in a nuclear staining pattern. (C-D) Higher power view 
differentiation in B-cell lymphomas [7], distinguishing different types of lymphomas [23], and evaluating the response to treatment [24]. In this study we have discovered for the first time that LMO2 is expressed with high-level in all ACCs, including high-grade transformed and zymogenpoor cases, with an intense cytoplasmic pattern, whereas other commonly seen salivary tumors seem to lack LMO2 expression, which may aid in the distinction between ACC and SC. However the possible biologic correlates of LMO2 overexpression in the tumorigenesis of ACC remains largely unknown, which awaiting further investigations.

Our findings suggest that $\mathrm{LMO} 2$ can be used as a novel marker for the recognition of ACC of salivary gland, which may aid in distinguishing ACC from its mimics, especially SC.

\section{Supplementary Information}

The online version contains supplementary material available at https://doi. org/10.1186/s13000-022-01192-w.

Additional file 1: Supplemetal Table 1. Summary of the pathological features of tumors in the salivary gland.

Additional file 2: Supplemental Table 2. Statistical analysis for cytoplasmic expression of LMO2 between acinic cell carcinomas and other tumors of the salivary gland.

\section{Acknowledgements}

Not applicable.

\section{Authors' contributions}

DS, YZ and X-Q L conceived and designed the research; X-Y Z and X-Q L provided the study materials or patients; DS, $Y Z$ and TX performed the research; DS analyzed the data; and DS and X-Q L wrote and reviewed the paper. All authors approved this manuscript.

\section{Funding}

This work was supported by a grant from the Guide Project of Science and Technology Commission of Shanghai Municipality (No. 134119a5000) and a grant from the Natural Science Foundation of Shanghai Municipality (No. 11ZR1407100)

\section{Availability of data and materials}

The datasets generated and/or analyzed during the current study are available from the corresponding author on reasonable request.

\section{Declarations}

\section{Ethics approval and consent to participate}

All methods were carried out in accordance with the relevant guidelines and regulations, and all the experimental protocols were approved for clinical use at Fudan University Shanghai Cancer Center. The use of human samples was approved by the Institutional Review Board of Fudan University Shanghai Cancer Center

\section{Consent for publication}

Consent for publication of the clinical details and pathological images was obtained and copies of the consent form are available.

\section{Competing interests}

The authors declare no conflicts of interests.
Received: 9 July 2021 Accepted: 30 December 2021

Published online: 30 January 2022

\section{References}

1. Chen AM, Garcia J, Granchi PJ, Johnson J, Eisele DW. Late recurrence from salivary gland cancer: when does "cure" mean cure? Cancer. 2008;112(2): 340-4. https://doi.org/10.1002/cncr.23165.

2. Skalova A, et al. Acinic cell carcinoma with high-grade transformation: a report of 9 cases with immunohistochemical study and analysis of TP53 and HER-2/neu genes. Am J Surg Pathol. 2009;33(8):1137-45. https://doi.org/10.1 097/PAS.0b013e3181a38e1c

3. Chiosea SI, Peel R, Barnes EL, Seethala RR. Salivary type tumors seen in consultation. Virchows Arch. 2009;454(4):457-66. https://doi.org/10.1007/ s00428-009-0742-x.

4. Skalova A, et al. Mammary analogue secretory carcinoma of salivary glands, containing the ETV6-NTRK3 fusion gene: a hitherto undescribed salivary gland tumor entity. Am J Surg Pathol. 2010;34(5):599-608. https://doi.org/1 0.1097/PAS.0b013e3181d9efcc

5. Matthews JM, Lester K, Joseph S, Curtis DJ. LIM-domain-only proteins in cancer. Nat Rev Cancer. 2013:13(2):111-22. https://doi.org/10.1038/nrc3418.

6. Morishima T, Krahl AC, Nasri M, Xu Y, Aghaallaei N, Findik B, et al. LMO2 activation by deacetylation is indispensable for hematopoiesis and T-ALL leukemogenesis. Blood. 2019;134(14):1159-75. https://doi.org/10.1182/ blood.2019000095.

7. Natkunam Y, Zhao S, Mason DY, Chen J, Taidi B, Jones M, et al. The oncoprotein LMO2 is expressed in normal germinal-center B cells and in human B-cell lymphomas. Blood. 2007;109(4):1636-42. https://doi.org/10.11 82/blood-2006-08-039024.

8. Thompson LD, Aslam MN, Stall JN, Udager AM, Chiosea S, McHugh JB. Clinicopathologic and Immunophenotypic characterization of 25 cases of Acinic cell carcinoma with high-grade transformation. Head Neck Pathol. 2016;10(2):152-60. https://doi.org/10.1007/s12105-015-0645-x.

9. Lei Y, Chiosea SI. Re-evaluating historic cohort of salivary acinic cell carcinoma with new diagnostic tools. Head Neck Pathol. 2012;6(2):166-70. https://doi.org/10.1007/s12105-011-0312-9.

10. Chenevert J, et al. DOG1: a novel marker of salivary acinar and intercalated duct differentiation. Mod Pathol. 2012;25(7):919-29. https://doi.org/10.1038/ modpathol.2012.57.

11. Patel KR, Solomon IH, el-Mofty SK, Lewis JS Jr, Chernock RD. Mammaglobin and S-100 immunoreactivity in salivary gland carcinomas other than mammary analogue secretory carcinoma. Hum Pathol. 2013:44(11):2501-8. https://doi.org/10.1016/j.humpath.2013.06.010.

12. Stevens TM, Kovalovsky AO, Velosa C, Shi Q, Dai Q, Owen RP, et al. Mammary analog secretory carcinoma, low-grade salivary duct carcinoma, and mimickers: a comparative study. Mod Pathol. 2015;28(8):1084-100. https://doi.org/10.1038/modpathol.2015.64.

13. Chiosea SI, Griffith C, Assaad A, Seethala RR. The profile of acinic cell carcinoma after recognition of mammary analog secretory carcinoma. Am J Surg Pathol. 2012;36(3):343-50. https://doi.org/10.1097/PAS.0b013e318242a5b0.

14. Bishop JA, Yonescu R, Batista D, Eisele DW, Westra WH. Most nonparotid "acinic cell carcinomas" represent mammary analog secretory carcinomas. Am J Surg Pathol. 2013;37(7):1053-7. https://doi.org/10.1097/PAS.0b013e3182841554.

15. Pinto A, Nosé V, Rojas C, Fan YS, Gomez-Fernandez C. Searching for mammary analogue [corrected] secretory carcinoma of salivary gland among its mimics. Mod Pathol. 2014:27(1):30-7. https://doi.org/10.1038/ modpathol.2013.84.

16. Urano M, Nagao T, Miyabe S, Ishibashi K, Higuchi K, Kuroda M. Characterization of mammary analogue secretory carcinoma of the salivary gland: discrimination from its mimics by the presence of the ETV6-NTRK3 translocation and novel surrogate markers. Hum Pathol. 2015;46(1):94-103. https://doi.org/10.1016/j.humpath.2014.09.012.

17. Haller F, Bieg M, Will R, Körner C, Weichenhan D, Bott A, et al. Enhancer hijacking activates oncogenic transcription factor NR4A3 in acinic cell carcinomas of the salivary glands. Nat Commun. 2019;10(1):368. https://doi. org/10.1038/s41467-018-08069-X.

18. Haller F, Skálová A, Ihrler S, Märkl B, Bieg M, Moskalev EA, et al. Nuclear NR4A3 immunostaining is a specific and sensitive novel marker for Acinic cell carcinoma of the salivary glands. Am J Surg Pathol. 2019:43(9):1264-72. https://doi.org/10.1097/PAS.0000000000001279.

19. Andreasen S, Varma S, Barasch N, Thompson LDR, Miettinen M, Rooper L et al. The HTN3-MSANTD3 fusion gene defines a subset of Acinic cell 
carcinoma of the salivary gland. Am J Surg Pathol. 2019;43(4):489-96. https://doi.org/10.1097/PAS.0000000000001200.

20. Mariano FV, Gómez CAC, de Souza do Nascimento J, dos Santos HT, Egal ES, Montalli VAM, et al. Lysozyme expression can be useful to distinguish mammary analog secretory carcinoma from Acinic cell carcinoma of salivary glands. Head Neck Pathol. 2016;10(4):429-36. https://doi.org/10.1007/s12105-016-0718-5.

21. Hung YP, Jo VY, Hornick JL. Immunohistochemistry with a pan-TRK antibody distinguishes secretory carcinoma of the salivary gland from acinic cell carcinoma. Histopathology. 2019;75(1):54-62. https://doi.org/10.1111/his.13845.

22. Skalova A, et al. Mammary analogue secretory carcinoma of salivary gland origin: an update and expanded morphologic and immunohistochemical spectrum of recently described entity. Head Neck Pathol. 2013;7(Suppl 1): S30-6. https://doi.org/10.1007/s12105-013-0455-y.

23. Brar N, Butzmann A, Kumar J, Peerani R, Morgan EA, Grigoriadis G, et al. LIM domain only 2 (LMO2) expression distinguishes T-lymphoblastic leukemia/ lymphoma from indolent T-lymphoblastic proliferations. Histopathology. 2020;77(6):984-8. https://doi.org/10.1111/his.14176.

24. Parvin S, Ramirez-Labrada A, Aumann S, Lu XQ, Weich N, Santiago G, et al. LMO2 confers synthetic lethality to PARP inhibition in DLBCL. Cancer Cell. 2019;36(3):237-49. https://doi.org/10.1016/j.ccell.2019.07.007.

\section{Publisher's Note}

Springer Nature remains neutral with regard to jurisdictional claims in published maps and institutional affiliations.

Ready to submit your research? Choose BMC and benefit from:

- fast, convenient online submission

- thorough peer review by experienced researchers in your field

- rapid publication on acceptance

- support for research data, including large and complex data types

- gold Open Access which fosters wider collaboration and increased citations

- maximum visibility for your research: over $100 \mathrm{M}$ website views per year

At BMC, research is always in progress.

Learn more biomedcentral.com/submissions 